\title{
ANALISIS TEKS ULASAN FILM DARI MEDIA ELEKTRONIK GOOGLE DAN PEMANFAATANNYA SEBAGAI BAHAN AJAR UNTUK SISWA SMP/MTS KELAS VIII
}

\author{
Karlinah $^{1)}$, Jaja ${ }^{2)}$ \\ ${ }^{1)}$ Mahasiswa Universitas Swadaya Gunung Jati, ${ }^{2)}$ Dosen Universitas Swadaya Gunung Jati \\ eka23190@gmail.com,jaja@unswagati.ac.id.
}

\begin{abstract}
ABSTRAK
Penelitian bertujuan untuk: (1) mengetahui struktur dan kebahasaan teks ulasan film; (2) mengetahui rancangan bahan ajar teks ulasan film; (3) mengetahui implementasi bahan ajar teks ulasan film. Penelitian ini menggunakan metode deskriptif analitik yang bertujuan mendeskripsikan data yang telah diperoleh dari hasil penelitian.Data yang digunakan dalam penelitian ini terdapat 3 teks ulasan film yang diperoleh dari media elektronik google.Teknik dalam mengumpulkan data, yaitu dokumentasi, simak, dan teknik catat.Hasil penelitian berupa rancangan bahan ajar handout teks ulasan film.Bahan ajar tersebut dapat digunakan untuk mempelajari struktur teks ulasan, kaidah kebahasaan teks ulasan, dan sajian tanggapan sebuah karya. Bahan ajar yang telah dirancang oleh peneliti akan melalui proses validitas terlebih dahulu sebelum diimplementasikan. Validitas dilakukan 3 tahap. Pertama, validasi yang dilakukan oleh dosen ahli bahasa Indonesia dari Universitas Swadaya Gunung Jati Cirebon. Kedua, validasi olehguru bahasa Indonesia dari SMPN 1 Kertasemaya. Ketiga, implementasi kepada 10 peserta didk SMPN 1 Kertasemaya.Data yang diperoleh dari hasil angket validasi, yaitu berikut ini. (1) Hasil validasi oleh dosen bahasa Indonesia memperoleh presentase 95\%. (2) Hasil validasi oleh guru bahasa Indonesia memperoleh presentase 100\%. (3) Nilai hasil implementasipeserta didik memperoleh presentase 95,97\%. Berdasarkan hasil angket validasi tersebut kemudian dijumlahkan dan mendapatkan hasil akhir 95,50\%. Persentase yang diperoleh menunjukan kriteria kelayakan bahan ajar handout teks ulasan film sangat valid atau dapat digunakan sebagai bahan pembelajaran teks ulasan film.
\end{abstract}

Kata kunci: alih kode, sosiolinguistik, tuturan

\section{A. PENDAHULUAN}

Teks ulasan merupakan salah satu kompetensi yang harus dikuasai oleh peserta didik dalam penerapan Kurikulum 2013. Teks ulasan sebelumnyadalam Kurikulum Tingkat Satuan Pendidikan dikenal dengan nama resensi. Kamus Besar Bahasa Indonesia(2008: 1522) mendefinisikanteks ulasan sebagai 'kupasan', 'tafsiran', atau 'komentar'. Jadi, teks ulasan ialah teks yang dihasilkan melaluikegiatan mengupas, menafsirkan, atau mengapresiasi suatu karya tertentu, misalnya buku, puisi, penayangan film, pementasan drama, lukisan, dan karyakarya lainnya. Dalam hal ini, Kosasih (2014: 204) menegaskan bahwa: 


\section{DEIKSIS - JURNAL PENDIDIKAN BAHASA DAN SASTRA INDONESIA}

Teks ulasan (film) merupakan hasil interpretasi terhadap suatu tayangan atau pementasan film tertentu.Dengan ulasan tersebut, pembaca atau penyimaknya menjadi terbantu dalam memahami suatu tayangan.Degan sinopsis, seseorang menjadi tahu isi ceritanya secara garis besar.Dengan membaca analisisnya, khalayak menjadi tahu struktur tayangan itu, sekaligus keunggulan dan kelemahannya.

Pembelajaran Kurikulum 2013 berbasis teks.Setiap teks yang dipelajari memiliki manfaat bagi peserta didik. Permendikbud No. 64 Tahun 2013 tentang Standar Isi menyatakan bahwa:

Dengan mempelajari teks ulasan peserta didik diharapkan memiliki prilaku jujur, percaya diri, tanggung jawab, kreatif, peduli, santun dalam merespons berbagai hal secara pribadi.Mengenal konteks budaya dan konteks sosial, satuan kebahasaan, serta unsur paralinguistik dalam menyajikan teks.Mengenal bentuk dan ciri teks dalam genre cerita, faktual, dan tanggapan.Memahami teks dalam genre cerita, faktual, dan tanggapan.Mengklasifikasi teks dalam genre cerita, faktual, dan tanggapan.Menemukan makna teks dalam genre cerita, faktual, dan tanggapan.Menyajikan teks dalam genre cerita, faktual, dan tanggapan secara lisan dan tulis.

Selain manfaat yang diperoleh oleh peserta didik dari mempelajari teks ulasan, pembaca atau penyimak juga akan terbantu untuk mengetahui secara garis besar isi karya yang diulas dari membaca teks ulasan tersebut. Hal ini sejalan dengan pendapat Kosasih (2014: 204) yang menyatakan bahwa dengan ulasan, pembaca menjadi terbantu dalam memahami suatu karya.

Kompetensi inti (KI) dan kompetensi dasar (KD) yang harus dicapai oleh peserta didik tertuang dalam Permendikbud No. 24 Tahun 2016 tentang Kompetensi Inti dan Kompetensi Dasar Kurikulum 2013 jenjang SMP/MTS.Terdapat empat kompetensi inti (KI) yang harus dicapai, tetapi hanya dua diajarkan dalam proses pembelajaran, yaitu KI 3 dan KI 4. Dua di antaranya secara tidak langsung dapat dimunculkan oleh tenaga pendidik disela-sela proses pembelajaran atau diluar proses pembelajaran.Kompetensi dasar (KD) 3 berisikan kompetensi memahami pengetahuan (faktual, konseptual, prosedural) berdasarkan rasa ingintahunya tentang ilmu pengetahuan, teknologi, seni, budaya terkait fenomena dan kejadian tampak mata, sedangkan KI 4 berisikan kompotensi mencoba, mengolah, dan menyajikan dalam ranah konkret (menggunakan, mengurai, merangkai, memodifikasi, dan membuat) dan ranah abstrak (menulis, membaca, menghitung, menggambar, dan mengarang) sesuai dengan yang dipelajari di sekolah dan sumber lain yang sama dalam sudut pandang teori. Adapun teks yang pelajari pada jenjang SMP kelas VIII terdiri atas sembilan teks, yaitu teks berita, iklan, eksposisi, puisi, eksplanasi, ulasan, persuasi, drama, dan tanggapan. KI3.Materi kompetensi KI 3 tersebut disajikan dalam buku teks siswa dengan kegiatan menentukan pernyataan yang berkenaan dengan teks ulasan yang sudah dibaca oleh peserta didik. Sementara 


\section{DEIKSIS - JURNAL PENDIDIKAN BAHASA DAN SASTRA INDONESIA}

itu materi KI 4 disajikan dalam bentuk kegiatan mencoba, mengolah, dan menyajikan data dengan menemukan struktur, menemukan kelebihan dan kekurangan teks ulasan. Dari semua kompetensi inti (KI) dan kompetensi dasar (KD) yang harus dicapai, peneliti hanya mengkajiKD 3.12 menelaah struktur dan kebahasaan teks ulasan (film, cerpen, puisi, novel, karya seni daerah) yang dibaca atau diperdengarkan; danKD 4.12 menyajikan tanggapan tentang kualitas karya (film, cerpen, puisi, novel, karya seni daerah) dalam bentuk teks ulasan secara lisaan dan tulis dengan memperhatikan struktur, dan kebahasaan, atau aspek lisan.

Adapun rumusan masalah penelitian ini yaitu 1) Bagaimanakah struktur dan kaidah kebahasaan teks ulasan film dari media elektronik google untuk mata pelajaran Bahasa Indonesia SMP/MTS kelas VIII? 2) Bagaimanakah rancangan bahan ajar handout struktur dan kaidah kebahasaan teks ulasan film dari media elektronik untuk Mata Pelajaran Bahasa Indonesia SMP/MTS kelas VIII? dan 3) Bagaimanakah hasil implementasi rancangan bahan ajar handout struktur dan kaidah kebahasaan teks ulasan film dari media elektronik google untuk Mata Pelajaran Bahasa Indonesia SMP/ MTS kelas VIII?

\section{B. METODOLOGI}

Metode yang digunakan dalam penelitian ini yaitu kualitatif. Data diperoleh dengan menggunakan teknik dokumentasi, angket, dan tes. Data yang terkumpul dianalisis dengan teknik deskriptif analitik dengan mengacu pada tahapan yang dikemukakan Sugiono (2014:21), yaitu sebagai berikut.

\section{Tahap Deskripsi}

Pada tahap ini data-data berupa dokumen teks ulasan yang diperoleh dari media elektronik google kemudian dianalisis untuk mengetahui struktur dan kaidah kebahasaan teks ulasan kemudian dideskripsikan.

\section{Tahap Reduksi}

Dasil analisis di atas kemudian dipilih dan dipilah lalu dideskripsikan untuk dijadikan bahan ajar.Selanjutnya, peneliti memvalidasi bahan ajar melalui angket yang diberikan kepada validator. Hasil angket yang telah peneliti peroleh dari dosen ahli dan guru bahasa Indonesia yang berupa skor nilai validasi bahan ajar handout. Kemudian data tersebut diuraikan secara naratif.

\section{Tahap Seleksi}

Pada tahap ini peneliti mengimplementasikan bahan ajar handout kepada peserta didik dan memberikan tugas berupa tes yang harus dijawab.Dari hasil tes tersebut kemudian dideskripsikan secara naratif.Pada tahap ketiga peneliti melakukan pencatatan hasil angket yang telah diperoleh dari validator dan peserta didik.Dari perhitungan hasil angket tersebut peneliti dapat mengetahui kebutuhan pembelajaran dan pada ahkirnya memperoleh bahan ajar handout yang layak.

\section{Tahap Simpulan}

Tahap terakhir dalam penelitian ini ialah menarik simpulan.Dalam penelitian ini, data yang diperoleh dari dokumentasi, angket validasi, dan tes dideskripsikan kemudian dianalisis sehingga diperoleh 


\section{DEIKSIS - JURNAL PENDIDIKAN BAHASA DAN SASTRA INDONESIA}

kesimpulan mengenai kelayakan handout sebagai bahan ajar.

\section{Kriteria Validasi Handout}

\begin{tabular}{|l|c|l|}
\hline No & $\begin{array}{c}\text { Kriteria } \\
\text { Validitas } \\
\text { (Pencapaian } \\
\text { skor) }\end{array}$ & \multicolumn{1}{|c|}{ Tingkat Validitas } \\
\hline 1. & $85,01 \%-100 \%$ & $\begin{array}{l}\text { Sangat valid atau dapat } \\
\text { digunakan tanpa revisi. }\end{array}$ \\
\hline 2. & $70,01 \%-85,00 \%$ & $\begin{array}{l}\text { Cukup valid atau dapat } \\
\text { digunakan tetapi, perlu } \\
\text { revisi kecil. }\end{array}$ \\
\hline 3. & $50,01 \%-70,00 \%$ & $\begin{array}{l}\text { Kurang valid, disarankan } \\
\text { tidak dipergunakan } \\
\text { karena perlu revisi besar. }\end{array}$ \\
\hline 4. & $01,00 \%-50,00 \%$ & $\begin{array}{l}\text { Tidak valid atau tidak } \\
\text { boleh dipergunakan. }\end{array}$ \\
\hline
\end{tabular}

(Akbar, 2013:41)

Berikut rumus perhitungan untuk menentukan nilai (\%) sesuai dengan kriteria keefektifan handout.

$$
\begin{aligned}
& \text { Validasi }=\frac{\text { Tse }}{\mathrm{TSh}} X \\
& 100 \%=\ldots \%
\end{aligned}
$$

Keterangan:

Tse $=$ Total skor empirik (hasil angket diperoleh dari angket validasi dosen dan guru ahli terhadap handout).

Tsh $=$ Total Skor maksimal (nilai maksimal dari keseluruhan angket).

\section{HASIL DAN PEMBAHASAN}

\section{Struktur dan Kebahasaan Teks} Ulasan

Suktur teks ulasan film terdiri dari lima, yaitu sebagai berikut. 1) Identitas karya, mencakup judul, bintang atau pemain film, sutradara, produser, sekenario, produksi, durasi. 2) Orientasi, terdapat pada paragraf pertama, berisi penjelasan keberadaan suatu karya yang akan diulas. 3) Sinopsis, berupa ringkasan yang menggambarkan pemahaman penulis terhadap isi film. 4) Analisis, berupa paparan tentang keberadaan unsur-unsur cerita, seperti tema, penokohan, dan alur. 5) Evaluasi, berisikan pemaparan kelebihan dan kekurangan suatu karya. Teks ulasan yang dianalisis berjudul Soekarno, Negeri 5 Menara, dan Hafalan Shalat Delisa. Ketiga teks tersebut memiliki struktur teks ulasan yang lengkap.

Adapun fitur kebahasaan teks ulasan yang dominan ada empat, yaitu 1) banyak menggunakan konjungsi penerang, contohnya bahwa, yakni 2) banyak menggunakan konjungsi temporal, misal sejak, semenjak, kemudian, akhirnya; 3) banyak menggunakan konjungsi penyebab, misal karena, sebab; 4) menggunakan pernyataan-pernyataan berupa opini, saran, atau rekomendasi pada bagian akhir teks. Contoh:jangan, harus, hendaknya, menurut saya. Pada teks yang berjudul Soekarno terdapat semua fitur di atas; pada teks yang berjudul Negeri 5 Menara hanya terdapat konjungsi (temporal dan penyebab); sedangkan pada teks yang berjudul Hafalan Shalat Delisa hanya terdapat konjungsi pernyataan rekomendasi.

\section{Desain Produk Awal Handout}

Hasil analisis di atas dijadikan bahan dasar untuk menyusun bahan ajar. Desain awal bahan ajar tersebut selanjutnyadivalidasi dosen ahli dan guru bahasa Indonesia dari aspek materi atau isi, penyajian materi, bahasa dan keterbacaan, dan grafika. Desainnya yaitu sampul depan 
dan belakang. Identitas bagian inti pada kegiatan belajar 1 terdapat contoh teks ulasan film Soekarno disertai dengan materi struktur teks ulasan film; Kegiatan belajar 2 memuat contoh teks ulasan filmNegeri 5 Menara disertai materi kebahasaan teks ulasan film; dan tugas. Adapun kompetensi yang diajarkanyaitu KD 3.12 Menelaah struktur dan kebahasaan teks ulasan (film, cerpen, puisi, novel, dan karya seni daerah) yang diperdengarkan dan dibaca dan $\mathrm{KD}$ 4.12 Menyajikan tanggapan tentang kualitas karya (film, cerpen, puissi, novel, dan karya seni daerah).

Dari angket diperoleh rekapitulasi data sebagai berikut.

\begin{tabular}{|c|c|c|c|c|}
\hline \multirow[b]{2}{*}{ No } & \multirow{2}{*}{$\begin{array}{c}\text { Aspek } \\
\text { Penilaian }\end{array}$} & \multicolumn{2}{|c|}{ Hasil Validasi } & \multirow{2}{*}{$\begin{array}{c}\text { Rata- } \\
\text { rata }\end{array}$} \\
\hline & & $\begin{array}{c}\text { Valida- } \\
\text { tor } 1\end{array}$ & $\begin{array}{l}\text { Valida- } \\
\text { tor2 }\end{array}$ & \\
\hline & Materi/isi & & & \\
\hline 1. & $\begin{array}{l}\text { Kesesuaian } \\
\text { materi dengan } \\
\text { KI dan KD. }\end{array}$ & 4 & 4 & 4 \\
\hline \multirow[t]{2}{*}{2.} & $\begin{array}{l}\text { Keefektifan } \\
\text { contoh-contoh } \\
\text { teks ulasan } \\
\text { film. }\end{array}$ & 4 & 4 & 4 \\
\hline & $\begin{array}{l}\text { Penyajian } \\
\text { Materi }\end{array}$ & & & \\
\hline 3. & $\begin{array}{l}\text { Kejelasan } \\
\text { tujuan } \\
\text { pembelajaran. }\end{array}$ & 4 & 4 & 4 \\
\hline \multirow[t]{2}{*}{4.} & $\begin{array}{l}\text { Keefektifan } \\
\text { penyajian } \\
\text { materi. }\end{array}$ & 4 & 4 & 4 \\
\hline & $\begin{array}{l}\text { Bahasa dan } \\
\text { Keterbacaan }\end{array}$ & & & \\
\hline 5. & $\begin{array}{l}\text { Kesesuain } \\
\text { penjelasan } \\
\text { handout } \\
\text { dengan } \\
\text { tingkat } \\
\text { keterbacaan } \\
\text { peserta didik. }\end{array}$ & 4 & 4 & 4 \\
\hline 6. & $\begin{array}{l}\text { Kesesuaian } \\
\text { penggunaan }\end{array}$ & 4 & 4 & 4 \\
\hline
\end{tabular}

\begin{tabular}{|l|l|c|c|c|}
\hline 7. & $\begin{array}{l}\text { bahasa. } \\
\begin{array}{l}\text { Keefektifan } \\
\text { penggunaan } \\
\text { bahasa. }\end{array}\end{array}$ & 3 & 4 & 3,5 \\
\hline 8. & $\begin{array}{l}\text { Kesesuaian } \\
\text { penggunaan } \\
\text { bahasa } \\
\text { dengan } \\
\text { kaidah bahasa } \\
\text { Indonesia. }\end{array}$ & 3 & 4 & 3,5 \\
\hline 9. & $\begin{array}{l}\text { Grafika } \\
\text { Ketepatan } \\
\text { pemakaian } \\
\text { ukuran dan } \\
\text { jenis huruf } \\
\text { (font). }\end{array}$ & 4 & 4 & 4 \\
\hline 10. & $\begin{array}{l}\text { Dan desain } \\
\text { tampilan } \\
\text { handout. }\end{array}$ & 4 & 4 & 4 \\
\hline & & & \\
\hline
\end{tabular}

Berdasarkan hasil validasi, bahan ajar dinyarakan valid atau layak untuk digunakan siswa. Hal ini terbukti dari hasil pengolahan data angket dengan menggunakan kriteria di atas, diperoleh persentase 95\% (validator dosen), $100 \%$ (validator guru), dan 95,97\% (penilaian siswa) atau rerata 95,50\%.

Hasil validisi juga menjadi masukan untuk perbaikan handoutkarena validator tidak hanya memberikan penilaian terhadap bahan ajar, tetapi juga memberikan saran atau perbaikan terhadap bahan ajar tersebut.

\section{Implementasi Handout Teks Ulasan Film pada Peserta Didik SMP Kelas VIII}

Implementasi bahan ajar dilakukan untukmenjawab rumusan masalah ketiga. Dari hasil implementasi diperoleh data sebagai berikut. 


\section{Data Hasil Analisis Tugas Peserta Didik}

\begin{tabular}{|c|l|c|c|c|}
\hline No. & \multicolumn{1}{|c|}{ Subjek } & T1 & T2 & $\begin{array}{c}\text { Nilai } \\
\text { Akhir }\end{array}$ \\
\hline 1. & $\begin{array}{l}\text { Peserta } \\
\text { Didik 1 }\end{array}$ & 100 & 100 & 200 \\
\hline 2. & $\begin{array}{l}\text { Peserta } \\
\text { Didik 2 }\end{array}$ & 100 & 100 & 200 \\
\hline 3. & $\begin{array}{l}\text { Peserta } \\
\text { Didik 3 }\end{array}$ & 90 & 100 & 190 \\
\hline 4. & $\begin{array}{l}\text { Peserta } \\
\text { Didik 4 }\end{array}$ & 100 & 100 & 200 \\
\hline 5. & $\begin{array}{l}\text { Peserta } \\
\text { Didik 5 }\end{array}$ & 90 & 100 & 190 \\
\hline 6. & $\begin{array}{l}\text { Peserta } \\
\text { Didik 6 }\end{array}$ & 100 & 100 & 200 \\
\hline 7. & $\begin{array}{l}\text { Peserta } \\
\text { Didik 7 }\end{array}$ & 100 & 100 & 200 \\
\hline 8. & $\begin{array}{l}\text { Peserta } \\
\text { Didik 8 }\end{array}$ & 100 & 100 & 200 \\
\hline 9. & $\begin{array}{l}\text { Peserta } \\
\text { Didik 9 }\end{array}$ & 100 & 100 & 200 \\
\hline 10 & $\begin{array}{l}\text { Peserta } \\
\text { Didik 10 }\end{array}$ & 100 & 100 & 200 \\
\hline
\end{tabular}

Berdasarkan perhitungan skor dengan menggunakan kriteriavalidasi di atas nilai rata-rata $89 \%$. Dengan demikian, bahan ajar handout dinyatakan layak dan dipahami peserta didik.

\section{SIMPULAN}

Berdasarkan hasil penelitian dan pembahasan di atas, peneliti menyimpulkan hasil penelitian sebagai berikut.

1. Dari analisis struktur terhadap teks ulasan film yang berjudul Soekarno, Negeri 5 Menara, dan Hafalan Shalat Delisa diperoleh struktur pembangun teks ulasan: (a) identitas karya, (b) orientasi, (c) sinopsis, (d) analisis, (e) evaluasi. Dari aspek kaidah kebahasaannya didapatidua kategori fitur penggunaan kaidah kebahasaan yang dominan digunakan, yaitu (a) konjungsi (penerang, temporal, dan penyebab) dan (d) kalimat yang menyatakan opini, saran, dan/atau rekomendasi.

2. Rancangan bahan ajarhandout teks ulasan film untuk siswa SMP/MTS kelas VIII layak digunakan guru dan siswa. Hal inidibuktikan dari hasil validitas dosen ahli sebesar 95\% dan dari guru bahasa Indonesia $100 \%$.

3. Hasil implementasi pada peserta didik kelas VIII SMPN 1 Kertasemaya Indramayu menunjukkan bahwa bahan ajar yang dikembangkan dapat dipahami peserta didik. Hal ini dibuktikan dengan rerata nilai $89 \%$.

\section{E. DAFTAR PUSTAKA}

Abidin, Y. (2014). Desain Sistem Pembelajaran dalam Konteks Kurikulum 2013. Bandung: Refika Aditama.

Akbar, Sa'dun. (2013). Instrumen Perangkat Pembelajaran.Bandung: Remaja Rosdakarya.

Arifin, Zaenal dan Tasai.(2005). Cermat $\begin{array}{llr}\text { Berbahasa Indonesia untuk } & \\ \text { Perguruan } & \text { Tinggi. } & \text { Jakarta: }\end{array}$

Akademik Pressindo.

Dalman.(2014). Keterampilan Menulis. Jakarta: Rajagrafindo Persada.

Daryanto.(2014). Menyusun Modul. Yogyakarta: Gava Media.

Hamdani.(2011). Strategi Belajar Mengajar. Bndung: Putaka setia.

Iskandarwassid,\& Sunendar. (2016). Strategi Pembelajaran Bahasa. Bandung: PT Remaja Rosdakarya. 


\section{DEIKSIS - JURNAL PENDIDIKAN BAHASA DAN SASTRA INDONESIA}

Kosasih. 2014. Jenis-jenis Teks. Bandung: Yrama Widya.

Kurniasih, I. (2014). Implementasi Kurikulum 2013 Konsep dan Pembelajaran. Surabaya: Kata Pena.

Mahsun.(2014). Teks dalam Pembelajaran Bahasa Indonesia Kurikulum 2013. Jakarta: Rajagrafindo.

Mulyadi.(2017). Bahasa Indonesia untuk SMP-MTS Kelas VIII. Bandung: Yarma Widya.

Nurdin, S., \& Adrianto.(2016). Kurikulum dan Pembelajaran. Jakarta: Rajawali Pers.

Prastowo, A. (2014). Pengembangan Bahan Ajar Tematik Tinjauan Teoretis dan Praktik. Jakarta: Kencana.

Prastowo, A. (2015). Panduan Kreatif Membuat Bahan Ajar Inofatif. Yogyakarta: Diva Press.

Prastowo, A. (2014). Pengembangan Bahan Ajar Tematik Tinjauan Teoretis dan Praktik. Jakarta: Kencana.

Priyatni, T. E. (2014). Desain Pembelajaran Bahasa Indonesia dalam Kurikulum 2013. Jakarta: Bumi Aksara.

Sudjana, N., \& Ibrahim.(2012). Penilaian dan Penelitian Pendidikan. Bandung: Sinar Baru Algensindo.

Sukmadinata, N,S., \& Syaodih. (2012). Kurikulum dan Pembelajaran Kompetensi. Bandng: PT Revika Aditama.

Widjono.(2005). Bahasa Indonesia. Jakarta: PT Grasindo.

Yaumi, M. (2013).Prinsip-prinsip Desain Pembelajarn. Jakarta: Kencana. https://www.tulismenulis.com/resensi-filmsoekarno/ diakses pada tanggal 08 November 2017.

http://www.bimbelbahasaindonesia.com/201 6/09/contoh-teks-ulasan-tentangfilm-negeri.html diakses pada tanggal 08 November 2017.

http://elipujilestari123.blogspot.co.id/2017/1 2/teks-ulasan-film-hafalan-sholatdelisa.html diakses pada tanggal 08 November 2017. 